\title{
An explorative comparison of self - perception and the perception of others concerning postoperative nausea and vomiting in infants
}

\author{
Fabian Veigl $^{1 *}$, Brigitte Messerer ${ }^{2}$, Alexander Avian, Andrea Berghold ${ }^{1}$ \\ From Safety in hospitals: from strategy to implementation Annual Scientific Meeting 2015 \\ Graz, Austria. 29-30 September 2015
}

\section{Background}

Quality assurance and process improvements of side effects are becoming more and more important in the context of an outcome orientated postoperative pain therapy [1-3]. In particular PONV (postoperative nausea and vomiting) leads to an impairment of patients' wellbeing. It can be assumed that the incidence exceeds the number of cases documented in the patient's chart. So the actual rate of PONV may be underestimated [4].

\section{Material and methods}

In a prospective, exploratory pilot study, standardized interviews were conducted with 40 patients, aged between 11 and 18, to analyse possible reasons of a missing report of PONV or the lack of documentation in the patient's chart. Furthermore associations between the incidence of PONV and the reporting-behavior of children with demographic data, process parameters, administered antiemetics or analgesics were evaluated.

\section{Results}

PONV was detected more frequently in the interviews $(\mathrm{n}=25,62.5 \%)$ than in the documentation $(\mathrm{n}=11$, $27.5 \%)$.

The results showed poor correlation between the interviews and the documentation regarding nausea but good congruency concerning vomiting. Minimal intensity of discomfort and the presumption that nausea would disappear by itself, led to missing report in the most cases. Dizziness, pain and postoperative opioid application were associated with the occurrence of

\footnotetext{
* Correspondence: fabian.veig|@gmail.com

'Institute for Medical Informatics, Statistics and Documentation, Medical University of Graz, Graz, Austria

Full list of author information is available at the end of the article
}

nausea. The reporting behavior increased significantly with the presence of the patients' parents.

\section{Conclusions}

The assumption that the actual incidence of PONV is hugely underestimated in children and adolescents was confirmed by these study results. Knowledge about the treatability of PONV, the form of information and the importance of early reporting behavior of nausea have to be improved based on data of this study.

Due to the lack of validation of the interviews and the exploratory study design, these results need to be confirmed in further studies.

\section{Authors' details}

${ }^{1}$ Institute for Medical Informatics, Statistics and Documentation, Medical University of Graz, Graz, Austria. ${ }^{2}$ Department of Anesthesiology and Intensive Care, Medical University of Graz, Graz, Austria.

Published: 30 October 2015

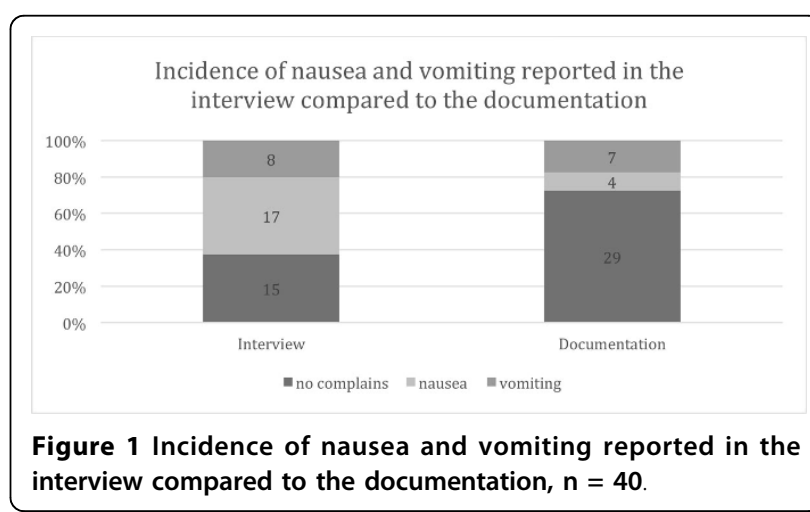




\section{References}

1. Rüsch D, Becke K, Eberhart LH, Franck M, Honig A, Morin AM, et al: Postoperative nausea and vomiting (PONV) - recommendations for risk assessment, prophylaxis and therapy - results of an expert panel meeting. Anasthesiol Intensivmed Notfallmed Schmerzther 2011, 46(3):158-170.

2. Kovac AL: Management of postoperative nausea and vomiting in children. Paediatr Drugs 2007, 9(1):47-69.

3. Phillips RS, Gopaul S, Gibson F, Houghton E, Craig JV, Light K, et al: Antiemetic medication for prevention and treatment of chemotherapy induced nausea and vomiting in childhood. Cochrane Database Syst Rev 2010, 9: CD007786.

4. Cohen MM, Duncan PG, DeBoer DP, Tweed WA: The postoperative interview: assessing risk factors for nausea and vomiting. Anesth Analg 1994, 78(1):7-16

\section{doi:10.1186/2056-5917-1-S1-A11}

Cite this article as: Veigl et al: An explorative comparison of self perception and the perception of others concerning postoperative nausea and vomiting in infants. Safety in Health 2015 1(Suppl 1):A11.

\section{Submit your next manuscript to BioMed Central} and take full advantage of:

- Convenient online submission

- Thorough peer review

- No space constraints or color figure charges

- Immediate publication on acceptance

- Inclusion in PubMed, CAS, Scopus and Google Scholar

- Research which is freely available for redistribution

Submit your manuscript at www.biomedcentral.com/submit
C Biomed Central 